\title{
Rancang Bangun Pagar Otomatis dengan Finger print Berbasis Mikrokontroller
}

\author{
Usman $^{1}$, Abdul Azis Rahmansyah ${ }^{2}$, Nur Fajri Apriadi ${ }^{3}$ \\ 1,2,3 Program Studi Teknik Listrik, Politeknik Bosowa \\ Jln. Kapasa Raya, No. 23, KIMA-Makassar 90245, Indonesia \\ E-mail : usman@politeknikbosowa.ac.id ${ }^{1}$, maxmicro.azis@gmail.com², Nurfajri.03.polybosowa@gmail.com ${ }^{3}$
}

\begin{abstract}
Abstrak
Pagar merupakan bagian keamanan terdepan dalam menjaga suatu bangunan. Pagar konvensional memerlukan operator untuk dapat membuka dan menutupnya sehingga tidak efektif dan effisien. Permasalahan ini dapat diatasi dengan sistem otomatis. Penelitian ini bertujuan untuk mendesain pagar dengan menggunakan sensor finger print yang berbasis mikrokontroller arduino, yang dilengkapi dengan pengunci menggunakan solenoid. Penelitian ini berupa experimental yang dimulai dari perancangan, pabrikasi dan pengujian. Pagar yang dibuat mempunyai spesifikasi $3.2 \mathrm{~m}$ x $1.5 \mathrm{~m}$ dengan total berat $30,67 \mathrm{Kg}$, panjang lintasan $210 \mathrm{~cm}$, diameter sprocket $3 \mathrm{~cm}$, Tegangan motor DC 12 Volt dan putaran $195 \mathrm{rpm}$. Hasil pengujian menunjukkan performa yang baik sesuai dengan desain awalnya, di mana pagar dapat terbuka dengan sidik yang telah direkam terlebih dahulu. Solenoid dapat membuka dan mengunci, begitupun dengan photodiode dapat mendeteksi adanya objek yang berada di atas rel. Hasil pengujian terdapat perbedaan waktu membuka/menutup dibandingkan dengan hasil desain sebesar 20\%, dengan rata-rata tegangan $12.06 \mathrm{~V}$, arus $1 \mathrm{~A}$, putaran $135 \mathrm{rpm}$, dan waktu yang dibutuhkan $9.9 \mathrm{~s}$ di mana torsi yang dihasilkan adalah sebesar $0.64 \mathrm{Nm}$ dan beban maksimal yang bisa digerakkan oleh motor DC adalah sebesar $59.97 \mathrm{~kg}$.
\end{abstract}

Kata Kunci: pagar otomatis, finger print, arduino uno, torsi dan beban maksimal

\begin{abstract}
The fence is one of the leading security in maintaining a building. Conventional fence require operator to open and close it, so it does not effective and efficient. This problem can be solved with automated systems. This research aims to design fance system using finger print sensor based microcontroller arduino, which is equipped with a locking system that use a solenoid. This experimental research is starts from the design, fabrication and testing. Fences made have specifications $3.2 \mathrm{~m} \times 1.5 \mathrm{~m}$ with a total weight is $30.67 \mathrm{~kg}$, path lengthis $2.1 \mathrm{~m}$, diameter sprocket $0.03 \mathrm{~m}$, Voltage DC motor is $12 \mathrm{~V}$ and rotation is $195 \mathrm{rpm}$. The test results showed a good performance conform with its initial design, where a fence can be opened with a fingerprint has been recorded before. Solenoid can open and lock, likewise with the the photodiode can detect object is on the track. The test results obtained there are differences when opening / closing compared with the results design is $20 \%$, with an average voltage is $12.06 \mathrm{~V}$, current is $1 \mathrm{~A}$, rotation is $135 \mathrm{rpm}$, and the time it takes $9.9 \mathrm{~s}$, where the torque produced is of $0.64 \mathrm{Nm}$ and maximum load can be driven by a DC motor is at $59.97 \mathrm{~kg}$.
\end{abstract}

Keywords: otomatic fences, finger print, arduino uno, torque and maximum load

\section{PENDAHULUAN}

Perkembangan teknologi instrumentasi elektronika dewasa ini sangat pesat, karena manusia membutuhkan bantuan dari sesuatu yang dapat bekerja cepat, teliti efektif dan dan effisien. Sebuah sistem yang otomatis akan sangat membantu manusia dalam kehidupan ataupun dalam menyelesaikan tugas sehari-hari. Dengan sistem yang otomatis ini peralatan-peralatan dikontrol dengan bantuan mesin yang telah diprogram sedemikian rupa sehingga manusia tidak lagi menjadi pengendali melainkan digantikan oleh mesin yang bekerja secara otomatis [1].

Pagar merupakan bagian terdepan dalam melindungi suatu bangunan. Sistem otomatis yang akan dibangun ini membutuhkan pengenal siapa saja yang dapat mengakses pagar tersebut, bagaimana cara menggerakkan pagar dan bagaimana cara mengunci pagar tersebut. Dengan demikian kita dapat merancang kebutuhan tersebut, misalnya untuk pengenal salah satunya dengan finger print untuk mengidentifikasi manusia berdasarkan sidik jarinya. Perangkat lain yang bisa digunakan misalnya sensor retina, smart face identification atau sensor suara. Untuk menggerakkan rangka dari pagar, kita dapat mengguanakan motor AC atau DC, pneumatics ataupun hidrolik. Sedangkan untuk sistem penguncian beberapa alat yang bisa digunakan seperti selenoid atau kunci magnetik.

Beberapa penelitian sebelumnya yang berkaitan dengan dengan penelitian ini yaitu [2] protitype pintu 
pagar otomatis berbasis arduino uno atmega $328 \mathrm{p}$ dengan sensor sidik jari. Hasil penelitian yang didapat adalah kecepatan putar optimal dan torsi optimal berada pada tegangan 18,3 - 21,6 Vdc. Dengan spesifikasi prototype, motor DC yang digunakan dapat menggerakkan benda dengan beban pagar hingga maksimal $50 \mathrm{~kg}$. Penelitian ini berfokus pada kinerja motor DC sebagai penggerak pagar, tidak menyajikan sistem penguncian pagar dan kondisi adanya objek di atas rel pada saat pagar akan menutup kembali. Penelitian oleh [3] yang membuat akses kontrol ruangan menggunakan sensor sidik jari berbasis mikrokontroller Atmega328p. Hasilnya adalah sensor sidik jari dan sensor gerak dapat berfungsi untuk membuka dan menutup sebuah pintu. Penelitian ini tidak secara eksplisit menjelaskan bagaimana proses membuka dan menutup pintu. Selanjutnya oleh [4] dengan penelitian perancangan palang kereta api otomatis berbasis mikrokontroller AT89S51 menggunakan sensor inframerah sebagai sensor halangan. Hasilnya sistem yang dibangun dapat berjalan, akan tetapi yang menjadi kendala penggunaan infra merah tidak efektif karena pembacaannya tidak bisa jauh dari objeknya.

Berdasarkan penjelasan di atas tujuan yang ingin dicapai dalam penelitian ini adalah merancang dan membuat suatu pagar yang dapat bekerja secara otomatis dengan menggunakan finger print sebagai pengidentifikasi. Dengan demikian fungsi pagar sebagi sistem pengaman pertama dalam suatu bangunan bisa terpenuhi dan dapat mengefisien dan mengefektifkan kerja manusia.

\section{TINJAUAN PUSTAKA}

Sistem otomatisasi peralatan dapat memberikan manfaat lebih dibandingkan dengan sistem konvensional. Sistem otomatis ini berkembang seiring dengan pesatnya berkembang ilmu pengetahuan dan teknologi saat ini. Pemanfaatan perkembangan teknologi ini dapat dimanfaatkan untuk dapat memudahkan, membuat lebih effisien ataupun untuk meningkatkan keamanan sebuah sistem. Ciri umum dari alat-alat yang bersifat otomatis adalah kehadiran komponen elektronik yang menjalankan fungsi pengendalian dan pengaturan [5].

Pagar merupakan bagian yang penting dalam sistem keamanan suatu rumah/bangunan, karena pagar sebagai pelapis pertama untuk melindungi suatu bangunan. Secara konvensional suatu pagar dibuka dan ditutup dengan menggunakan tenaga manusia. Banyak permasalahan keamanan suatu bangunan atau rumah karena pagar yang dapat diakses oleh semua orang, ataupun efektifitas kinerja manusia tidak tercapai secara maksimal dengan menggunakan pagar yang konvensional. Dengan kemajuan teknologi pagar dapat membuka dan menutup secara otomatis dengan menggunakan perangkat elektronika [2,6].

Berikut penjelasan komponen utama yang digunakan dalam sistem pagar otomatis ini.

Finger print : merupakan divais yang dapat membaca pola guratan-guratan pada kulit tangan manusia. Sistem biometrik ini banyak digunakan karena memiliki keakurasian yang tinggi, mudah dimanfaatkan dan masing-masing individu bebrbeda-beda, sehingga aplikasi untuk sekuritas atau akses kontrol sangat tepat digunakan. [3]. Salah satu jenis finger print adalah Fingerprint ZFM-20, modul finger print inilah yang digunakan dalam penelitian ini. Modul sensor ini dilengkapi dengan (Digital Signal Processing) DSP yang melakukan image rendering, kemudian mengkalkulasi, feature-finding dan terakhir searching pada data yang sudah ada.

Limit Switch ; jenis sakelar yang dilengkapi dengan katup yang berfungsi menggantikan tombol. Prinsip kerja limit switch sama seperti sakelar push on yaitu menghubung pada saat katubnya ditekan pada batas penekanan tertentu dan akan memutus saat saat katub tidak ditekan [7].

Arduino uno : sebuah board mikrokontroller yang berbasis pada mikrokontroller ATmega328. Arduino uno memiliki 14 buah pin yang dapat difungsikan sebagai input/output digital, sehingga dapat dihubungkan dengan perangkat input seperti sensor, selain itu juga dapat dihubungkan dengan perangkat output. Mikrokontroller ini dapat beroperasi pada tegangan $5 \mathrm{~V}$ [8].

Motor DC ; mesin yang mengubah energi listrik arus searah menjadi energi mekanis yang berupa putaran. Motor DC dapat diganti arah putarannya dengan mengganti polaritas sumber tegangan. Dengan sifat ini motor ini banyak digunakan untuk berbagai aplikasi yang ditunjang dengan kecepatannnya tetap pada kondisi bertammbahnya beban [3]. Karakteristik motor DC diketahui dengan kurva yang menggambarkan hubungan torka dengan kecepatannya, seperti yang ditunjukkan pada Gambar 1. Gambar tersebut menjelaskan bahwa torka motor DC berbanding terbalik dengan kecepatannya. Dua sifat dari grafik tersebut yaitu stall torque, titik dengan torsi maksimum akan tetapi motor tidak berputar dan no load speed, merupakan titik dimana motor berputar maksimum akan tetapi motor dalam keadaan tanpa beban [2].

Berdasarkan kurva pada Gambar 5 diperoleh fungsi torsi atau kecepatan sudut sebagai berikut.

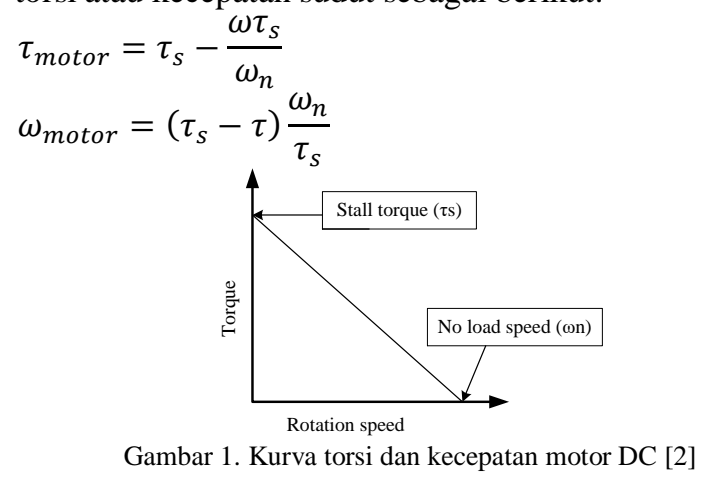

Sensor Photodiode ; sensor cahaya semikonduktor yang dapat mengubah besaran cahaya menjadi besaran listrik. Divais bekerja berdasarkan intensitas cahaya, jika terkena cahaya maka akan bekerja seperti dioda pada umumnya tetapi jika tidak mendapat cahaya maka akan berperan seperti resistor dengan nilai tahanan yang besar sehingga arus listrik tidak dapat mengalir [9]. 


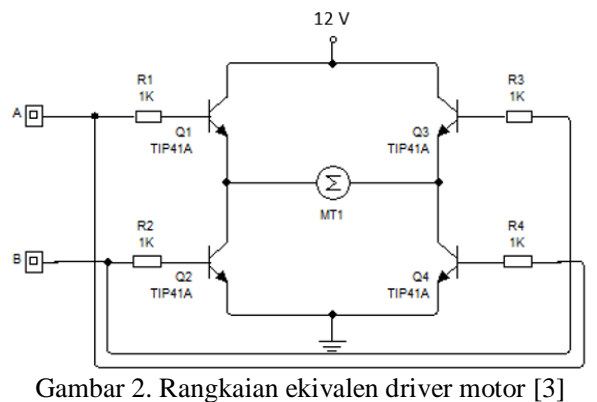

LASER ; suatu alat yang memancarkan radiasi elektromagnetik, biasanya dalam bentuk cahaya yang tidak dapat dilihat maupun dapat lihat dengan mata normal, melalui proses pancaran terstimulasi [10].

Driver Motor ; digunakan untuk sistem kontrol motor DC. Kontrol motor yang dimaksud adalah mengatur putaran motor yaitu forward atau reevers [4]. Driver yang digunakan dalam penelitian ini adalah jenis $\mathrm{H}-$ Bridge. Driver terdiri dari 4 buah transistor dimana transistor Q1 dan Q4 di trigger bersama, supaya ada aliran arus dari titik A ke B pada motor DC sehingga rotor akan berputar clock wise. Ketika arah putaran motor akan dibalik, maka transistor Q2 dan Q3 yang akan di trigger bersama, sehingga arus pada motor DC akan mengalir dari titik B ke A Gambar 2.

Solenoid ; peralatan yang dipakai untuk mengkonversi arus listrik menjadi gerak mekanik. Solenoid dibuat dari kumparan dan inti besi yang dapat digerakkan, dan berfungsi sebagai aktuator untuk membuka kunci otomatis.

\section{METODE}

\section{Rancangan Penelitian}

Rancangan sistem pagar secara otomatis ini menggunakan pemindai sidik jari untuk dapat membuka pagar dan selenoid untuk menguncinya. Sebagai penggerak digunakan motor DC dengan gear box yang dikopel dengan sprocket dan rantai. Untuk mengidentifikasi adanya sebuah objek yang berada di atas rel akan dideteksi oleh sensor photodiode. Secara lengkap desain sistem ini dapat dilihat pada blok diagram Gambar 3.

Pagar yang akan dibuat berbahan baja ringan dengan spesifikasi $1.40 \mathrm{~m}$ x $3.2 \mathrm{~m}$, panjang lintasan $2.80 \mathrm{~m}$ dan roda penggerak sebanyak 3 (tiga) buah dengan diameter $8 \mathrm{~cm}$. Desain rancangan mekanik sistem pagar otomatis ini ditunjukkan oleh Gambar 4. Desain rangkaian elektronik untuk sistem ini menggunakan sistem tegangan $12 \mathrm{~V}$ dan $5 \mathrm{~V}$. Sedangkan rancangan software ini dapat di lihat dalam Gambar 5.

\section{Analisis Data}

Parameter yang akan diukur meliputi, tegangan (V), arus (A), putaran (rpm), daya (W) dan waktu (s) membuka dan menutup pagar. Sedangkan untuk waktu membuka dan menutup akan dibandingkan dengan menggunakan persamaan berikut :

$k \odot=\pi d$

$l_{t}=\frac{r p m}{60}$

$t=k \odot \times l_{t}$

dimana : $k \odot=$ keliling sprocket $(\mathrm{m}), \pi=$ phi, $d=$ diameter sprocket, $l_{t}=$ panjang lintasan sprocket selama $t$ detik dan $r p m=$ putaran motor DC

Untuk mengitung torsi motor pada saat bekerja dan beban maksimal yang bisa diputar oleh motor adalah

$\tau=\frac{P}{\omega}$

$\omega=\frac{2 \pi n}{60}$

dimana : $\tau=$ torka $(\mathrm{Nm}), P=$ daya (watt) dan $\omega=$ kecepatan sudut ( $\mathrm{rad} / \mathrm{s})$

\section{HASIL DAN PEMBAHASAN}

\section{Hasil Perancangan Mekanik}

Hasil fabrikasi rancang bangun pagar otomatis ini mempunyai spesifikasi dengan berat $3.6 \mathrm{~kg}$, panjang lintasan pagar $2.82 \mathrm{~m}$, diameter sproket $0.03 \mathrm{~m}$, panjang rantai $3.2 \mathrm{~m}$, jumlah mata gigi sproket 15 buah. Secara visual ditunjukan Gambar 6. Sumber listrik yang digunakan adalah sistem DC dengan nominal power suplay 5 dan $12 \mathrm{~V}$ yang diperoleh rectivier. Sebagai back up sistem kelistrikannya menggunakan baterai dan inverter untuk mengubah tegangan DC mencadi AC.

\section{Pengujian Sistem}

Pengujian sistem meliputi pengujian buka tutup pagar otomatis secara keseluruhan. Kemudian diukur beberapa variabel yang meliputi tegangan, arus pada motor DC, putaran dan waktu yang dibutuhkan oleh pagar untuk membuka dan menutup. Hasil pengujian sistem ini disajikan pada Tabel 1dan Tabel 2.

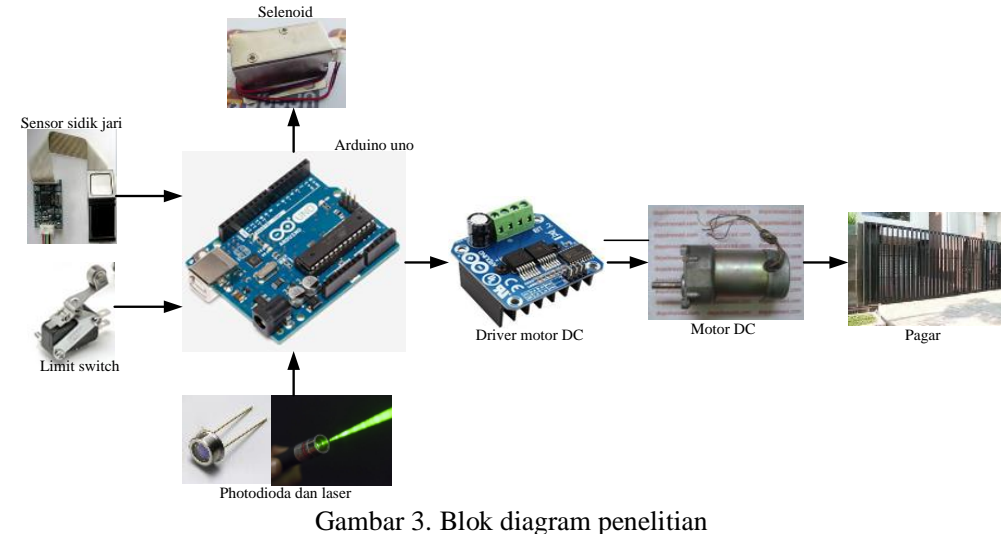




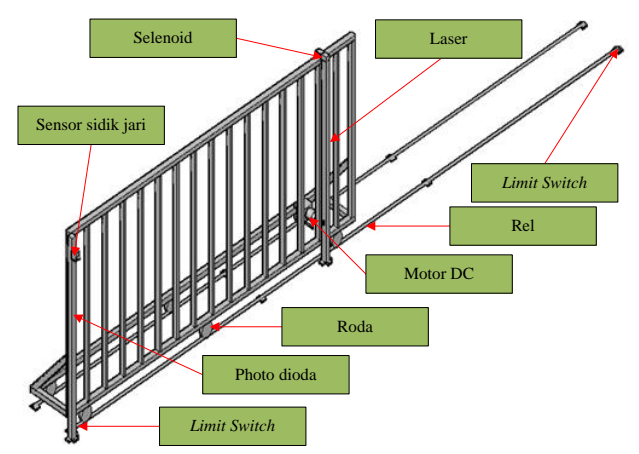

Gambar 4. Desain mekanik pagar.

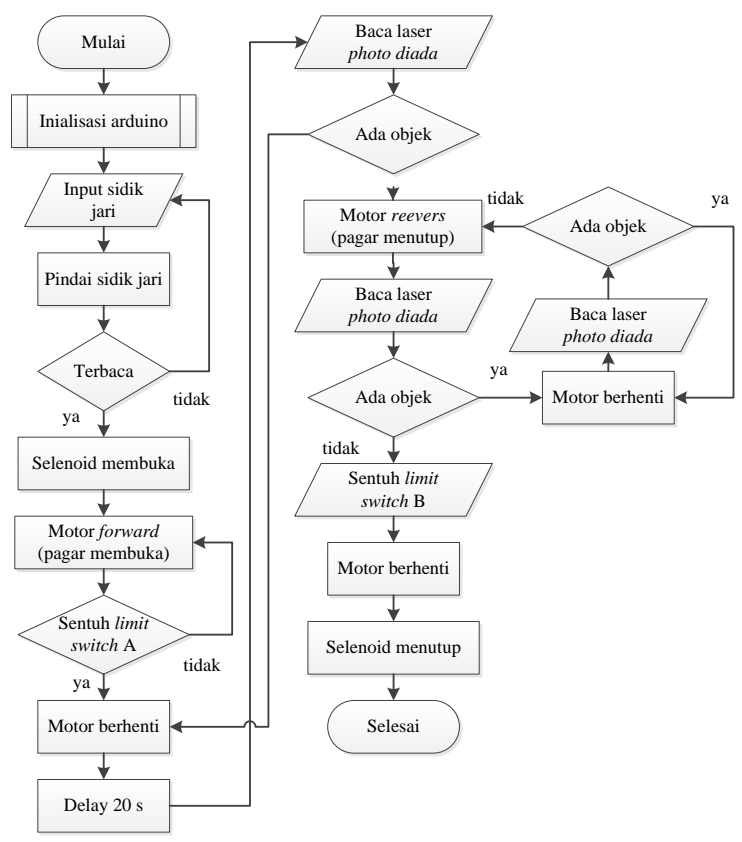

Gambar 5. Flowchart program arduino.

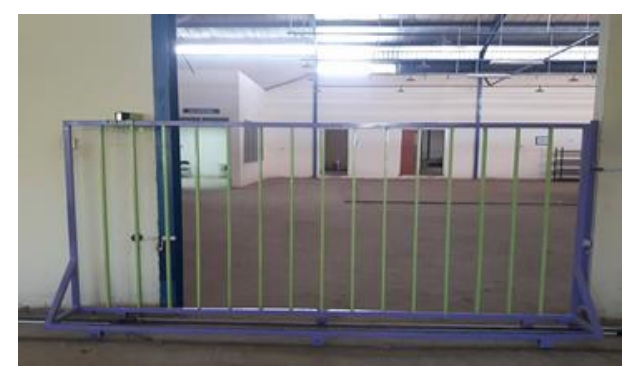

Gambar 6. Hasil fabrikasi rancangan pagar.

Tabel 1. Hasil pengujian sistem

\begin{tabular}{|l|c|c|c|c|c|c|}
\hline \multirow{2}{*}{$\begin{array}{c}\text { Finger print } \\
\text { (Valid/tidak valid) }\end{array}$} & \multicolumn{2}{|c|}{ Selenoid } & \multicolumn{2}{c|}{$\begin{array}{c}\text { Objek } \\
\text { di lintasan }\end{array}$} & \multicolumn{2}{c|}{ Motor } \\
\cline { 2 - 7 } & Buka & Kunci & Ada & Tidak & Berputar & Berhenti \\
\hline \multirow{2}{*}{ Valid } & $\sqrt{ }$ & & & $\sqrt{ }$ & $\sqrt{ }$ & \\
\cline { 2 - 7 } & & $\sqrt{ }$ & $\sqrt{ }$ & & & $\sqrt{ }$ \\
\hline Tidak valid & & $\sqrt{ }$ & & & & $\sqrt{ }$ \\
\hline
\end{tabular}

Tabel 2. Hasil pengujian membuka dan menutup pagar.

\begin{tabular}{|c|c|c|c|c|c|c|c|c|c|c|}
\hline \multirow[b]{2}{*}{ Uji } & \multicolumn{5}{|c|}{ Membuka Pagar } & \multicolumn{5}{|c|}{ Menutup Pagar } \\
\hline & $\begin{array}{l}\text { Tegangan } \\
\text { Motor } \\
\text { (V) }\end{array}$ & $\begin{array}{c}\text { Arus } \\
\text { Motor } \\
\text { (A) }\end{array}$ & $\begin{array}{c}\text { Daya } \\
\text { Motor } \\
(W)\end{array}$ & $\begin{array}{c}\text { Putaran } \\
\text { (rpm) }\end{array}$ & $\begin{array}{c}\text { Waktu } \\
\text { (s) }\end{array}$ & $\begin{array}{c}\text { Tegangan } \\
\text { Motor } \\
\text { (V) }\end{array}$ & $\begin{array}{l}\text { Arus } \\
\text { Motor } \\
\text { (A) }\end{array}$ & $\begin{array}{l}\text { Daya } \\
\text { Motor } \\
(W)\end{array}$ & $\begin{array}{c}\text { Putaran } \\
\text { (rpm) }\end{array}$ & $\begin{array}{c}\text { Waktu } \\
\text { (s) }\end{array}$ \\
\hline $\mathrm{I}$ & 12.2 & 1.1 & 11.4 & 139 & 9.6 & 12.3 & 0.7 & 11.2 & 134 & 10 \\
\hline II & 11.7 & 0.9 & 7.2 & 134 & 10 & 12 & 0.65 & 9.6 & 131 & 10.2 \\
\hline III & 12.1 & 1.1 & 10.1 & 139 & 9.6 & 12.2 & 0.7 & 9.2 & 134 & 10 \\
\hline IV & 11.8 & 1 & 8.8 & 136 & 9.7 & 12 & 0.65 & 9.7 & 131 & 10.2 \\
\hline $\mathrm{V}$ & 11.8 & 1 & 8.6 & 136 & 9.8 & 12.5 & 0.75 & 11.7 & 136 & 9.8 \\
\hline
\end{tabular}



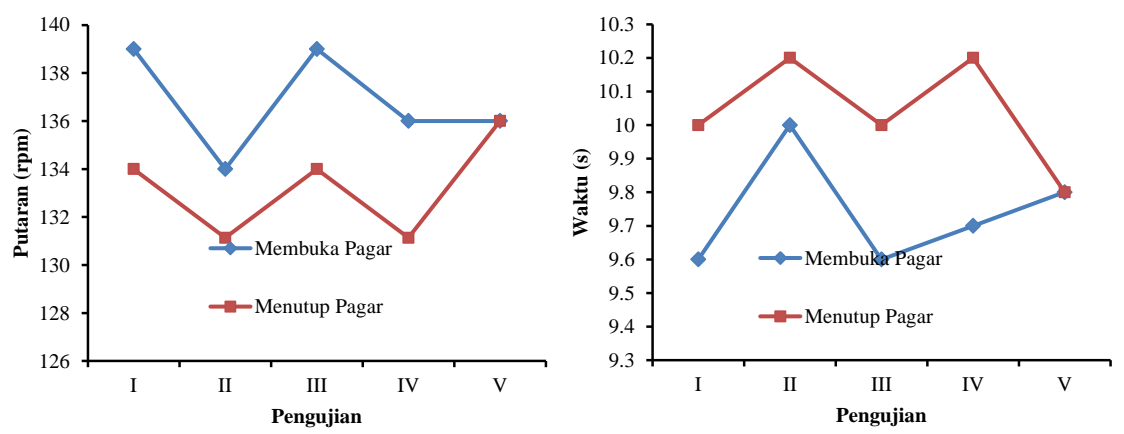

Gambar 7. Grafik perbandingan membuka dan menutup pagar (a) putaran dan (b) waktu.

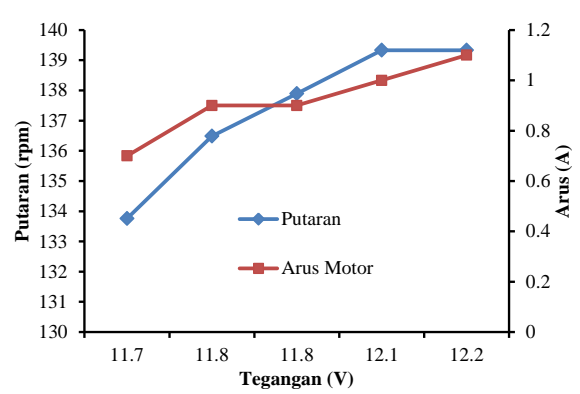

Gambar 8. Grafik perbandingan tegangan terhadap putaran dan arus pada motor DC pada kondisi pagar membuka

Waktu yang dibutuhkan oleh pagar untuk menutup dan membuka dengan menggunakan persamaan (3-5) didapatkan $8.2 \mathrm{~s}$. Apabila dibandingkan dengan hasil pengukuran waktu yang dibutuhkan untuk membuka dan menutup rata-rata sebesar $9.89 \mathrm{~s}$ atau berbeda sebesar $20 \%$. Perhitungan secara teoritik di atas tidak memperhitungkan beban pada motor tersebut. Fenomena ini disebabkan karena bertambahnya torsi pada motor DC, karena adanya beban sebesar 30,67 $\mathrm{Kg}$. penambahan torsi ini akan menyebabkan penurunan kecepatan seperti yang ditunjukkan oleh karakteristik motor DC pada Gambar 9. Berdasarkan gambar tersebut dapat dilihat bahwa kenaikan torsi dapat menyebabkan penurunan putaran [11]. Fenomena ini juga dapat diverifikasi dengan penelitian oleh [2].

Secara umum torsi merupakan gaya yang digunakan untuk menggerakkan sesuatu dengan jarak dan arah tertentu. Dari persamaan (9-10) dimana $P_{\text {rata-rata }}=$ $9.22 \mathrm{~W}$ dan $n_{\text {rata-rata }}=136.8 \mathrm{rpm}$ maka torsi yang dihasilkan adalah $0.64 \mathrm{Nm}$ atau $0.06 \mathrm{~kg} . \mathrm{m}$ yang dihitung berdasarkan persamaan (6). Sedangkan beban maksimal yang bisa diputar oleh motor DC ini dengan tegangan kerja $12 \mathrm{~V}$, dihitung dengan menggunakan persamaan (7), diperoleh beban sebesar $59.97 \mathrm{~kg}$.

\section{Pengembangan}

Penerapan sistem pagar otomatis sudah cukup banyak diterapkan, seiring dengan perkembangan teknologi kontrol dan elektronika serta tuntutan keamanan. Di lain pihak sistem otomatis dapat memberikan efektivitas dan efisiensi yang lebih baik. Dengan demikian penelitian yang seperti ini perlu keberlanjutan untuk mendapatkan metode atau device baru yang bisa lebih meningkatkan kinerja, keamanan dan efektifitas serta keekonomiannya.

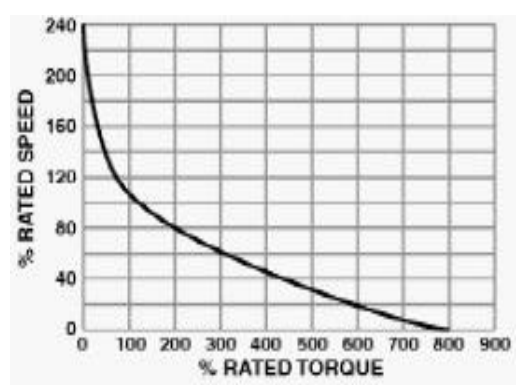

Gambar 9. Grafik hubungan torka terhadap kecepatan motor DC [11].

Kedepannya perlu penelitian lebih lanjut mengenai penggunaan motor induksi sebagai penggerak karena beroperasi dengan tegangan AC sehingga tidak diperlukan rectifier mempunyai reliability dan juga mempunyai torka yang besar, effisiensi yang relatif tinggi, kerugian gesekan rendah, ekonomis dan biaya pemeliharaan yang rendah. Akan tetapi motor ini mempunyai starting awal yang tinggi dan putarannya susah diatur, tetapi bisa dimanupulasi dengan menggunakan gear box untuk menurunkan putarannya [12]. Selain itu untuk lebih meningkatkan keamanan bisa menambahkan divais pengidentifikasi misalnya dengan menggunakan voice detector atau menggantikan finger print. Pemakaian voice detector bisa lebih meningkatkan effisiensi karena kita tidak perlu bersentuhan langsung dengan divaisnya cukup kita mengeluarkan suara. Misalnya pada saat kita bekendara kita tidak pelu turun untuk menepelkan jari kita pada finger print. Menurut [13] voice detector mempunyai kelebihan seperti kehandalan, ketahanan, akurasi, adaptasi dan kesederhanaan. Untuk alasan keamanan divais ini mempunyai karakteristik yang sama dengan sidik jari, setiap manusia mempunyai frekuensi suara yang berbeda-beda yang megakibatkan karateristik sura manusia berbeda-beda pula.

\section{PENUTUP}

\section{Kesimpulan}

Berdasarkan hasil pengujian, sistem pagar otomatis ini sudah dapat berfungsi sesuai dengan perancangan, dimana semua blok dari sistem ini menunjukkan indikator keberhasilan. Hasil pengujian didapatkan perbedaan waktu membuka/menutup dibandingkan dengan hasil desain sebesar $20 \%$, dengan rata-rata tegangan $11.92 \mathrm{~V}$, arus $0.92 \mathrm{~A}$, putaran $136.8 \mathrm{rpm}$ pada motor DC, dan waktu yang dibutuhkan $9.74 \mathrm{~s}$ pada saat membuka pagar. Sedangkan pada saat menutup rata-rata 
tegangan motor $12.2 \mathrm{~V}$, arus $1.08 \mathrm{~A}$, putaran $133.3 \mathrm{rpm}$, dimana torsi yang hasilkan adalah sebesar $0.64 \mathrm{Nm}$ dan beban maksimal yang bisa digerakan oleh motor DC yang dipakai adalah sebesar $59.97 \mathrm{~kg}$.

\section{Saran}

Untuk penelitian lebih lanjut, perlu diperhatikan rancangan mekanik terkait dengan cara menggerakan pagar, supaya mempunyai gaya gesek yang rendah, sehingga menghasilkan putaran yang lebih konstan. Selain itu seperti yang dibahas sebelumnya perlu penletian lanjut untuk menggantikan jenis motor penggerak dan sensor pendeteksi objek pada lintasan.

\section{Ucapan Terima Kasih}

Pada kesempatan ini penulis mengucapkan terima kasih kepada Maryam dan Muh.Agung Izurhaq yang telah banyak membantu dalam proses penelitian ini.

\section{Kesimpulan}

Berdasarkan hasil pengujian, sistem pagar otomatis ini sudah dapat berfungsi sesuai dengan perancangan, dimana semua blok dari sistem ini menunjukkan indikator keberhasilan. Hasil pengujian didapatkan perbedaan waktu membuka/menutup dibandingkan dengan hasil desain sebesar $20 \%$, dengan rata-rata tegangan $11.92 \mathrm{~V}$, arus $0.92 \mathrm{~A}$, putaran $136.8 \mathrm{rpm}$ pada motor DC, dan waktu yang dibutuhkan $9.74 \mathrm{~s}$ pada saat membuka pagar. Sedangkan pada saat menutup rata-rata tegangan motor $12.2 \mathrm{~V}$, arus $1.08 \mathrm{~A}$, putaran $133.3 \mathrm{rpm}$, dimana torsi yang hasilkan adalah sebesar $0.64 \mathrm{Nm}$ dan beban maksimal yang bisa digerakan oleh motor DC yang dipakai adalah sebesar $59.97 \mathrm{~kg}$.

\section{Saran}

Untuk penelitian lebih lanjut, perlu diperhatikan rancangan mekanik terkait dengan cara menggerakan pagar, supaya mempunyai gaya gesek yang rendah, sehingga menghasilkan putaran yang lebih konstan. Selain itu seperti yang dibahas sebelumnya perlu penletian lanjut untuk menggantikan jenis motor penggerak dan sensor pendeteksi ada tidak objek yang ada pada rel.

\section{Ucapan Terima Kasih}

Pada kesempatan ini penulis mengucapkan terima kasih kepada Maryam dan Muh.Agung Izurhaq yang telah banyak membantu dalam proses penelitian ini.

\section{DAFTAR PUSTAKA}

[1] Irvan Nanda Prawira, "Perancangan dan Pembuatan Sistem Parkir Otomatis Menggunakan Koin Berbasis Mikrokontroller AT89S52 Secara Hardware," Medan, Skripsi 2010.

[2] Yogie El Anwar, Noer Soedjarwanto, and Ageng Sadnowo Repelianto, "Prototype Penggerak Pintu Pagar Otomatis Berbasis Arduino uno," Volume 9, No. 1, Januari 2015, vol. 9, no. 1, pp. 30-41, Januari 2015.

[3] Dony Saputra, Abdul Haris Masud, Muhamad
Ramdhan, and Dian Fitriani, "Akses Kontrol Ruangan Menggunakan Sensor Sidik Jari Berbasis Mikrokontroler Atmega328p," in Seminar Nasional Teknologi Informasi dan Komunikasi, Yogyakarta, 2014, pp. 596-604.

[4] Renova Simanulang, "Perancangan Palang Kereta Api Otomatis Berbasis Mikrokontroler AT89S51 Menggunakan Sensor Inframerah Sebagai Sensor Halangan," Fisika Instrumen, Universitas Sumatra Utara, Medan, Tugas Akhir 2009.

[5] Marlin Malluka and Indra Surjati, "Model Sistem Otomatisasi Pengisian Ulang Air Minum," Tesla, vol. 10, no. 2, pp. 97-102, Oktober 2008.

[6] Wibowo, Sunu Hasta, "Simulasi Pengontrolan Pintu Garasi Otomatis," Jurnal Intekna, pp. 1-9, 2014.

[7] Yudhy Wiranatha Jaya Kusuma, Noer Soedjarwanto, Agus Trisanto, and Dikpride Despa, "Rancang Bangun Penggerak Otomatis Panel Surya Menggunakan Sensor," Rekayasa dan Teknologi Elektro, vol. IX, no. 1, pp. 11-20, Januari 2015. [Online].

[8] Zainal Abidin and Susmini Indriani Lestariningati, "Sistem Keamanan dan Monitoring Rumah Pintar Secara Online Menggunakan Perangkat Mobile," Komputika, vol. III, no. 2, pp. 13-17, 2014.

[9] Christoforus Yohannes, "Sistem Penghitung Jumlah Barang Otomatis Dengan Sensor Ultrasonik," Elektrikal Enjiniring, vol. IX, no. 2, pp. 66-71, Agustus 2012.

[10] C Hadi P, "Rancang Bangun Alat Pemilah dan Penghitung Barang dengan Menggunakan Laser Berbasis Mikrokontroller," Universitas Negeri Suarabaya, Surabaya, Skripsi 2014.

[11] Bambang Hidayat and Syamsul Amien, "Pengaruh Pegaturan Kecepatan Menggunakan Metode Pengaturan Fluksi Terhadap Efisiensi Pada Motor Arus Searah," Singuda Ensikom, vol. IX, no. 2, pp. 86-91, November 2014.

[12] Yusnita and Hendro Tjahjono, "Sistem Pengendali Arus Start Motor Induksi Phasa Tiga Dengan Variasi Beban," Jurnal Teknik Elektro ITP, vol. I, no. 2, pp. 19-23, Januari 2012.

[13] M. H. Moattar and M. M. Homayounpour, "A Simple But Efficient Real-Time Voice Activity Detection Algorithm," in 17th European Signal Processing Conference (EUSIPCO 2009), Glasgow, Scotland, 2009, pp. 2549-2553. 